\title{
UJI KONSENTRASI BUNUH MINIMAL (KBM) INFUSUM DAN AIR PERASAAN \\ DAUN BINAHONG (ANREDERA CORDIFOLIA) TERHADAP BAKTERI \\ SALMONELLA TYPHI DAN STAPHYLOCOCCUS AUREUS SECARA IN-VITRO
}

Wawan Sofwan Zaini, Nining Kurniati, Arief Fadillah

Poltekkes Kemenkes Banten

\begin{abstract}
ABSTRAK
Daun binahong (A.cordifolia) merupakan salah satu tanaman obat tradisional yang memiliki banyak manfaat, di antaranya sebagai obat batuk, diabetes, sesak nafas, luka bakar, luka pasca operasi, disentri, radang ginjal, radang usus, jerawat, gusi berdarah, melancarkan haid, penambah nafsu makan, dan meningkatkan daya tahan tubuh. Daun binahong mengandung berbagai macam zat aktif, yaitu alkaloid, saponin, flavonoid dan polifenol yang memiliki daya antibakteri. Di Indonesia penyakit infeksi oleh bakteri masih menjadi masalah kesehatan, maka perlu dikembangkan suatu bahan alam yang dapat dimanfaatkan sebagai alterbatif pengobatan, salah satunya adalah daun binahong. Penggunaan daun binahong di masyarakat untuk pengobatan sudah lama digunakan, namun perlu dilakukan penelitian secara ilmiah untuk menunjukkan khasiat dan dosis yang tepat. Dicoba dilakukan penelitian efektivitas antibakteri dari infusum dan air perasan daun binahong terhadap bakteri Salmonella typhi dan Staphylococcus aureus secara in-vitro dengan menentukan konsentrasi bunuh minimal dengan variasi waktu kontak menggunakan metode serial dilution. Penelitian ini merupakan penelitian eksperimental laboratorium dengan desain penelitian menggunakan Rancangan Acak Kelompok (RAK) di mana dilakukan perlakuan pada bakteri uji dengan variasi konsentrasi dan waktu kontak infusum dan air perasan daun binahong. Untuk kontrol negatif menggunakan aquades steril $(0 \%)$ dan sebagai pembanding digunakan tetrasiklin dan khloramfenikol. Hasil penelitian menunjukkan bahwa infusum daun binahong dengan konsentrasi 60\% dengan waktu kontak 60 menit memiliki daya hambat terhadap pertumbuhan S.typhi dan pada konsentrasi $80 \%$ dengan waktu kontak 180 menit terhadap S.aureus. Sedangkan Air perasan daun binahong dengan konsentrasi $100 \%$ dengan waktu kontak 90 menit memiliki daya hambat terhadap S.typhi, dan konsentrasi 100\% dengan waktu kontak 60 menit terhadap S.aureus
\end{abstract}

\section{Kata kunci : Daun Binahong (Anredera Cordifolia), Bakteri Salmonella Typhi, Staphylococcus Aureus}

Korespondensi: Wawan Sofwan Zaini . E-mail: wawan.sofwan.zaini@poltekkesbanten.ac.id

PENDAHULUAN

Di era modern ini pola hidup masyarakat yang kurang memperhatikan kebersihan lingkungan mengakibatkan munculnya penyakit infeksius. Saat ini semboyan back to nature sering di dengungkan, mulai dari perilaku hidup, pola makan, hingga pengobatan penyakit. Dalam menyembuhkan berbagai macam penyakit, tanaman obat telah menjadi kebutuhan yang 
banyak diminati oleh masyarakat, karena selain aman, biaya yang dikeluarkan relatif murah dibandingkan dengan obat-obatan yang berbahan dasar sintesis ${ }^{1}$. Penggunaan obat kimia memiliki efek samping yang bisa berupa efek samping langsung maupun tidak langsung atau terakumulasi.Hal ini terjadi karena bahan kimia bersifat anorganik dan murni sementara tubuh bersifat organik dan kompleks.Maka bahan kimia bukan bahan yang benar-benar cocok untuk tubuh.Penggunaan bahan kimia pada tubuh dianggap sebagai sesuatu yang tidak terhindarkan dan digunakan secara terbatas yang dapat diterima dan ditoleransi oleh tubuh $^{2}$.

Di berbagai daerah di Indonesia banyak tumbuhan yang dapat digunakan untuk pengobatan berbagai macam penyakit, salah satunya yaitu Binahong (Anredera cardifolia). Kandungan di dalam daun binahong terdapat aktifitas antioksidan, asamaskorbat dan total fenol yang cukup tinggi. Zat-zat tersebut mampu melawan bakteri Gram positif seperti Staphylococcus aureus. Serta mampu juga melawanenam bakteri Gram negatif seperti Enterobacter cloacae, Eshcherichicoli, Klebsiella pneumoniae, Pseudomonas aeruginosa, Serratia marcescens, dan Enterobacter aerogenes ${ }^{3}$.
Secara umum, daun binahong dapat mempercepat pemulihan kesehatan setelahoperasi, melahirkan, khitan, segala luka-luka dalam, radang usus, melancarkan danmenormalkan peredaran dan tekanan darah, mencegah stroke, maag, asam urat,menambah dan mengembalikan vitalitas daya tahan tubuh, wazir (ambeien),melancarkan buang air kecil, buang air besar, diabetes, demam tifoid, sakit pinggang, dan lain-lain ${ }^{3}$.

Demam tifoid merupakan salah satu penyakit menular di masyarakat yang disebabkan infeksi oleh bakteri Salmonella typhi. ${ }^{4}$. Demam tifoid banyak ditemukan di negara, atau daerah-daerah yang kurang mempertahankan kebersihan baik air maupun makanannya. Infeksi demam tifoid tertinggi sering dijumpai pada pada anak-anak ${ }^{5}$. Infeksi dapat terjadi melalui mulut, dari makan dan minuman yang terkontaminasi bakteri Salmonella typhi. Makanan yang biasanya tercemar meliputi kue-kue yang mengandung saus susu, daging cincang, sosis unggas, dan telur. Walaupun penular dan orang sakit dapat mencemari makanan dan minuman, sumber infeksi oleh bakteri Salmonellosis adalah hewan tingkat rendah. Banyak spesies bakteri Samonella terdapat secara alamiah pada ayam, kalkun, bebek, binatang pengerat, kucing, anjing, dan banyak lagi hewan lainnya ${ }^{6}$. 
Individu-individu tersebut dapat mengeluarkan berjuta-juta bakteri Samonella dalam tinjanyayang merupakan sumber pencemar makan dan minuman baik secara langsung atau melalui lalat sebagai vektornya $^{7}$. Demam tifoid bila tidak segera diobati dapat menyebabkan kematian 10-20\%. Karna terjadi ulcus pada usus usus halus, dimana dapat terjadi perforasi usus, perdarahan usus, toksemia, dan komplikasi lainya. $^{(7,8)}$

Tujuan penelitian untuk mengetahui konsentrasi terendah infusum daun binahong yang masih dapat membunuh bakteri Salmonella typhi dan Staphylococcus aureus

\section{METODE}

Desain Penelitian menggunakan Rancangan Acak Kelompok (RAK) di mana dilakukan perlakuan pada bakteri uji dengan variasi konsentrasi dan waktu kontak infusum dan air perasan daun binahong. Penelitian bersifat Eksperimental laboratorium. Sampel yang digunakan dalam penelitian kali ini adalah infusum dan air perasan daun binahong dalam berbagai konsentrasi. Bakteri uji adalah strain murni bakteri Salmonella typhi dan Staphylococcus aureus, yang didapatkan dari isolate penderita demam tifoid. Dilaksanakan di Laboratorium Mikrobiologi Jurusan Analis Kesehatan. Tahapan penelitian meliputi :
1. Sortasi daun binahong yang akan digunakan

2. Pencucian daun binahong sampai bersih

3. Dilakukan proses pembuatan infusum daun binahong terpilih sebanyak 100 gram ditambahkan $100 \mathrm{ml}$ air pada suhu $90^{\circ} \mathrm{C}$ selama 15 menit

4. Dilakukan proses pembuatan perasan daun binahong terpilih sebanyak 100 gram, diblender, kemudian disaring dengan kain khas. Dilakukan dengan teknik aseptik

5. Setelah mendapatkan infusum dan air perasan (dianggap 100\%), kemudian dibuat pengenceran sampai didapatkan konsentrasi 40\%, 60\%, 80\% dan 100\%. Dilakukan proses sentrifugasi (diberikan pelarut)

6. Dilakukan uji aktivitas antibakteri dengan variasi konsentrasi dan waktu kontak

\section{HASIL}

Penelitian ini menggunakan kontrol media, kontrol negative dan kontrol positive. Kontrol media yang digunakan adalah media salmonella shigella agar (SSA) dan media manitol salt agar (MSA) dalam cawan petri yang tidak ditanami bakteri Salmonella typhi dan S.aureus. Kontrol negative yang digunakan dalam penelitian ini adalah aquades sebagai pengganti bakteri sedangkan kontrol positive yang digunakan adalah media 
salmonella shigella agar (SSA) dan media manitol salt agar (MSA) dalam cawan petri yang ditanami bakteri S. typhi dan S.aureus.

Berdasarkan dari penelitian yang telah dilakukan mengenai uji konsentrasi bunuh minimal (KBM) infusum daun binahong (Anredera cordifolia) terhadap bakteri Salmonella typhi dan S.aureus secara in-vitro didapatkan hasil pengujiannya pada tabel sebagai berikut :

Tabel 1

Pengujian infusum daun binahong terhadap S.typhi

\begin{tabular}{llccc}
\hline Bakteri uji & \multicolumn{4}{c}{ Salmonella typhi } \\
konsentrasi & 30 & 60 & 90 & 180 \\
$(\%)$ & menit & menit & menit & menit \\
\hline 40 & + & + & + & + \\
60 & + & - & - & - \\
80 & - & - & - & - \\
100 & - & - & - & - \\
\hline
\end{tabular}

Dilihat dari table di atas digunakan pengujian infusum daun binahong terhadap S.typhi dengan konsentrasi 40\%, 60\%, 80\%, dan $100 \%$ dengan berbagai waktu kontak untuk masing-masing konsentrasi dan didapatkan hasil negative tanpa adanya pertumbuhan koloni bakteri terjadi pada konsentrasi $60 \%$ dengan waktu kontak 60 menit.

Tabel 2

Pengujian infusum daun binahong terhadap S.aureus

\begin{tabular}{llllc}
\hline Bakteri uji & \multicolumn{4}{c}{ S.aureus } \\
$\begin{array}{l}\text { konsentrasi } \\
\text { (\%) }\end{array}$ & menit & menit & menit & menit \\
\hline 40 & + & + & + & + \\
60 & + & + & + & + \\
80 & + & + & + & + \\
100 & + & + & - & - \\
\hline
\end{tabular}

Dilihat dari table di atas digunakan pengujian infusum daun binahong terhadap S.aureus dengan konsentrasi 40\%, 60\%, 80\%, dan $100 \%$ dengan berbagai waktu kontak untuk masing-masing konsentrasi dan didapatkan hasil negative tanpa adanya pertumbuhan koloni bakteri terjadi pada konsentrasi $100 \%$ dengan waktu kontak 90 menit.

\section{Tabel 3}

Pengujian air perasan daun binahong terhadap S.typhi

\begin{tabular}{llccc}
\hline Bakteri uji & \multicolumn{4}{c}{ Salmonella typhi } \\
$\begin{array}{l}\text { konsentrasi } \\
\text { (\%) }\end{array}$ & menit & menit & menit & menit \\
\hline 40 & + & + & + & + \\
60 & + & + & + & + \\
80 & + & + & + & - \\
100 & - & - & - & - \\
\hline
\end{tabular}

Dilihat dari table di atas digunakan pengujian air perasan daun binahong terhadap S.typhi dengan konsentrasi $40 \%, 60 \%, 80 \%$, dan $100 \%$ dengan berbagai waktu kontak untuk masing-masing konsentrasi dan didapatkan hasil negative tanpa adanya 
pertumbuhan koloni bakteri terjadi pada konsentrasi $80 \%$ dengan waktu kontak 180 menit.

Tabel 4

Pengujian air perasan daun binahong terhadap

S.aureus

\begin{tabular}{llccc}
\hline Bakteri uji & \multicolumn{4}{c}{ S.aureus } \\
konsentrasi & 30 & 60 & 90 & 180 \\
$(\%)$ & menit & menit & menit & menit \\
\hline 40 & + & + & + & + \\
60 & + & + & + & + \\
80 & + & + & + & + \\
100 & + & - & - & - \\
\hline
\end{tabular}

Dilihat dari table di atas digunakan pengujian air perasan daun binahong terhadap S.aureus dengan konsentrasi 40\%, 60\%, 80\%, dan $100 \%$ dengan berbagai waktu kontak untuk masing-masing konsentrasi dan didapatkan hasil negative tanpa adanya pertumbuhan koloni bakteri terjadi pada konsentrasi $100 \%$ dengan waktu kontak 60 menit.

\section{PEMBAHASAN}

Pemanfaatan tanaman obat sebagai alternative untuk pengobatan dalam mengatasi permasalahan kesehatan banyak dijumpai di Indonesia. Salah satunya pemanfaatan tanaman sebagai bahan obat alam yang memiliki efek antibakteri. Pemakaian antibiotic yang tidak sesuai dosis dapat menimbulkan efek negative dan menyebabkan terjadinya resistensi antibiotic. Sehingga usaha usaha pencarian senyawa antimikroba baru sering dilakukan untuk mengurangi efek resistensi dari antibiotic.

Di dalam daun binahong (Anredera cardifolia) terdapat aktivitas antioksidan, asamaskorbat dan total fenol yang cukup tinggi. Zat-zat tersebut mampu melawan bakteri Gram positif seperti Staphylococcus aureus. Serta mampu juga melawan enam bakteri Gram negatif seperti Enterobacter cloacae, Eshcherichia coli,Klebsiella pneumoniae, Pseudomonas aeruginosa, Serratia marcescens, dan Enterobacter aerogenes ${ }^{3}$. Hasil penelitian Khunaif M (2010) menunjukkan bahwa ekstrak daun binahong mempunyai konsentrasi bunuh minimal sebesar 50\% terhadap S.aureus.

Berdasarkan hasil penelitian tanaman binahong memiliki kandungan zat aktif yang berguna untuk tubuh. Berikut ini dielaskan berbagai macam kandungan zat aktif yang terdapat pada tumbuhan binahong, di antaranya Antioksidan, asamaskorbat dan total fenol yang cukup tinggi dan Minyak asitri yang bermanfaat sebagai anti bakteri dan anti radang. Aktivitas biologis senyawa flavonoid yang bersifat larut dalam air terhadap bakteri dengan merusak membran sitoplasma dari bakteri yang terdiri dari asam amino dan lipid 
dengan mereaksikannya dengan gugus alkohol yang terdapat pada senyawa flavonoid.

Aktivitas antibakteri terhadap bakteri uji ditunjukkan dengan tumbuhnya koloni pada media pertumbuhan dan pengujian aktivitas antibakteri ini dilakukan untuk mengetahui potensi antibakteri dari infusum dan air berasan daun binahong. Bakteri uji yang digunakan yaitu Bakteri strain murni Salmonella typhi dan Staphylococcus aureus, yang didapatkan dari isolate penderita demam tifoid yang merupakan penyakit berbahaya dan termasuk kelompok bakteri gram negatif.

Setelah dilakukan uji konsentrasi bunuh minimal (KBM) didapatkan bakteri Salmonella typhi tidak tumbuh koloni pada konsentrasi infusum 60\% dengan waktu kontak 60 menit dan pada konsentrasi air perasan $80 \%$ dengan waktu kontak 180 menit. Sedangkan pada bakteri Staphylococcus aureus tidak tumbuh koloni pada konsentrasi infusum $100 \%$ dengan waktu kontak 90 menit dan pada konsentrasi air perasan $100 \%$ dengan waktu kontak 60 menit.

Berdasarkan data tersebut dapat diketahui bahwa infusum dan air perasan daun binahong dapat membunuh bakteri dalam uji bunuh minimal terhadap bakteri Salmonella typhi dan Staphylococcus aureus.

\section{SIMPULAN}

Berdasarkan hasil dan pembahasan yang telah dibuat dapat disimpulkan bahwa infusum dan air perasan daun binahong memiliki potensi sebagai antibakteri dan dapat membunuh bakteri Salmonella typhi dan Staphylococcus aureus. Hasil uji aktivitas antibakteri terhadap Salmonella typhi adalah pada konsentrasi infusum $60 \%$ dengan waktu kontak 60 menit dan pada konsentrasi air perasan $80 \%$ dengan waktu kontak 180 menit. Sedangkan terhadap Staphylococcus aureus pada konsentrasi infusum 100\% dengan waktu kontak 90 menit dan pada konsentrasi air perasan $100 \%$ dengan waktu kontak 60 menit.

\section{DAFTAR PUSTAKA}

1. Prayudi Y. Warta Balai Penelitian Tanaman Rempah dan Obat. 2009.h.6.

2. Tomayahu, Rahma. Identifikasi Senyawa Aktif dan Uji Toksisitas Ekstrak Daun Binahong ( anredera cordifolia ten. Steenis) Dengan Metode brine shrimp lethality test (bslt). Gorontalo : Skripsi. Fakultas Matematika dan Ilmu Pengetahuan Alam. Universitas Negeri Gorontalo. 2014

3. Sabir, A. In Vitro Antibacterial Activity Of Flavonoids Trigona Sp Propolis Against Streptococcus mutans. Terdapat pada

http://www.journal.unair.ac.id/filerPDF/

DENTJ-38-3-08.pdf. Di akses pada bulan Maret 2017 
4. Jawetz, Melnick, dan Adelberg, Mikrobiologi Kedokteran, Penerbit Salemba Medika, Jakarta, 2005.

5. Rochani, N., Uji Aktivitas Antijamur Ekstrak Daun Binahong (Anredera cordifolia (Tenore) Steen) Terhadap Candida albicans Serta Skrinning Fitokimianya, Skripsi, Universitas Muhammadiyah, Surakarta, 2009

6. Sulistyani S. Uji Efek Ekstrak Etanol 70\% Daun Binahong (Anredera Cordifolia Steenis) Terhadap Kadar Alt (Alanin Aminotransferase) pada Tikus Jantan Galur Wistar (Rattus Norvegicus) yang Di Induksi dengan Parasetamol. Kedok Journal. 2013. h.3

7. Rahmawati, Lin., Enny, F. Dewi, K. Isolasi, Identifikasi dan Uji Antioksidan Senyawa Flavonoid Daun Binahong (Anredera cordifolia (Ten.) Steenis). Semarang. Universitas Diponegoro, 2007

8. Davis WW, Stout TR. Disc Plate Method Of Microbiology Antibiotic Assay. Microbiology Edisi 2. Jakarta 1971; 22(4): 659-65.

9. Paju, Niswah. Yamlean, V.Y. Paulina., Kojong, Novel. Uji Efektivitas Salep Ekstrak Daun Binahong (Anredera cordifolia (Ten.) Steenis) pada Kelinci (Oryctolagus cuniculus) yang Terinfeksi Bakteri Staphylococcus aureus. 1(2): 2302-2493. 2013.

10. Murdianto, Agus Ria., Enny, F. Dewi, K. Isolasi, Identifikasi Serta Uji Aktivitas Antibakteri Senyawa Golongan Triterpenoid Dari Ekstrak Daun Binahong (Anredera cordifolia (Ten.) Steen) Terhadap Staphylococcus aureus dan Escherichia coli. Universitas Diponegoro Semarang, 2009.
11. Badan Penelitian dan Pengembangan Kesehatan Departemen Kesehatan RI Laporan Hasil Riset Kesehatan Dasar (Riskesdas) Nasional, Jakarta;2013

12. Manoi, F. Binahong (Andera cordifolia)(Ten) steenis sebagai Obat.Jurnal Warta penelitian dan Pengembangan Tanaman Industri.Volume 15 Nomor 1:3. 2009.

13. Ainurrochma, A., Evie, R., Lisa, L. Efektivitas Ekstrak Daun Binahong (Anredera cordifolia) terhadap Penghambatan Pertumbuhan Bakteri Shigella flexneri dengan Metode Sumuran. 3(2): 233-237. 2013.

14. Saputra S. Pengaruh Ekstrak Daun Binahong (Anredera Cordifolia Steenis) Terhadap Pertumbuhan Salmonella Typhi. Journal. 2008. h.1 